\title{
Dispersal Patterns of Subadult and Adult Colorado Squawfish in the Upper Colorado River
}

\author{
D. B. OSMUNDSON* \\ U.S. Fish and Wildlife Service, Colorado River Fishery Project \\ 764 Horizon Drive, South Annex A, Grand Junction, Colorado 81506-3946, USA \\ R. J. RYEL \\ Utah State University, Department of Rangeland Resources, Logan, Utah 84322-5230, USA \\ M. E. TUCKER ${ }^{1}$ AND B. D. BuRdick \\ U.S. Fish and Wildife Service, Colorado River Fishery Project \\ W. R. ELMBLAD \\ Colorado Division of Wildlife, 711 Independent Avenue, Grand Junction, Colorado 81505, USA \\ T. E. CHART \\ Utah Division of Wildlife Resources, 1165 South Highway 191, Suite 4, Moab, Utah 84532, USA
}

\begin{abstract}
We investigated distribution and dispersal patterns of subadult and adult Colorado squawfish Ptychocheilus lucius (recently renamed the Colorado pikeminnow) throughout their range in the upper Colorado River. Annual, river-wide, capture-recapture data were used to document movements during a 5-year period (1991-1995). Average total length of Colorado squawfish progressively increased upstream: juveniles and subadults occurred almost exclusively in the lowermost $105 \mathrm{~km}$ of the $298-\mathrm{km}$ study area, whereas most adults were concentrated in the uppermost $98 \mathrm{~km}$. This was most pronounced early in the study and less so later due to the effect of two or three strong year-classes that dispersed through the system. Only $16 \%$ of subadult and adult fish initially captured and tagged in the upper reach were later located more than $10 \mathrm{~km}$ from the previous capture site; of those tagged in the lower reach, 58\% were later located more than 10 $\mathrm{km}$ from the previous site. Most movements greater than $10 \mathrm{~km}$ were directed upstream, and many fish tagged in the lower reach moved to the upper reach; the smallest of these fish was between 421 and $449 \mathrm{~mm}$ in total length (TL) when it moved. No movement was detected from the upper reach to the lower. Distance moved was inversely related to fish size: displacement of fish shorter than $550 \mathrm{~mm}$ TL averaged $33.6 \mathrm{~km}$; for those longer than $550 \mathrm{~mm}$, average displacement was only $7.5 \mathrm{~km}$. Movement of young adults may have been a response to changing food needs. Upstream movements placed fish into areas with greater availability of larger prey, and body condition of large adults during spring was significantly higher in the upper reach than in the lower reach. Water temperatures, however, were inversely related to adult distribution despite a preference for warmer water. We suggest that portions of the upper reach offer adults the best balance between food and water temperature.
\end{abstract}

\section{Introduction}

Understanding the life history of the endangered Colorado squawfish Ptychocheilus lucius (recently renamed the Colorado pikeminnow; Nelson et al. 1998) is prerequisite to developing strategies for its recovery. This warmwater piscivore, endemic to the Colorado River system and the largest cyprinid native to North America, has integrated

\footnotetext{
* Corresponding author: doug_osmundson@fws.gov

${ }^{1}$ Present address: U.S. Fish and Wildlife Service, Northern Central Valley Fish and Wildlife Office, 10950 Tyler Road, Red Bluff, California 96080, USA.
}

movements into its life strategies. Annual, potamodromous, spawning migrations (e.g., Tyus and McAda 1984; Tyus 1985, 1990; McAda and Kaeding 1991; Ryden and Ahlm 1996), and downstream drift of emerging larvae (e.g., Haynes et al. 1984; Nesler et al. 1988; Tyus 1990; Tyus and Haines 1991) have been well documented.

Longitudinal differences in fish size within the Colorado (Valdez et al. 1982; Osmundson and Burnham 1998, this issue) and Green (Tyus 1986) rivers suggest that movements may serve purposes or functions in addition to those associated with reproduction. Early life stages are found primarily in lower reaches, whereas adults are found pri- 


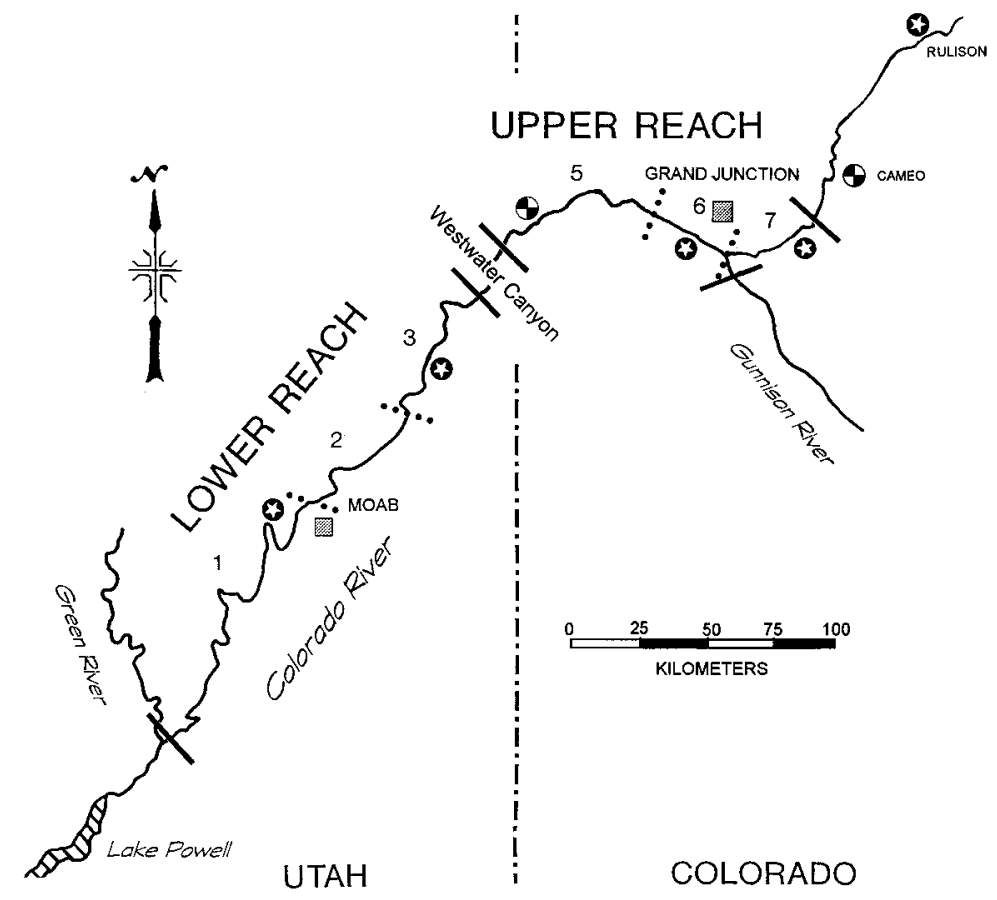

FiguRE 1.-Map of the study area. The lower boundary is the Green River confluence. Upper and lower study reaches are separated by Westwater Canyon. Also marked are the upper ends of the study area on the Colorado and Gunnison rivers where diversion dams blocked upstream movement of fish. Dotted lines demarcate the boundaries of the seven study strata (numbered). Starred circles are locations of U.S. Fish and Wildlife Service thermographs; crossed circles are locations of U.S. Geological Survey gauging stations with thermographs.

marily in more upstream reaches. The best spawning habitat ostensibly occurs in middle to upper reaches, and long-distance drift provides a mechanism for delivering emerging larvae to optimal nursery habitat, generally located far downstream (Tyus 1990). With young fish primarily in lower river reaches, higher concentrations of adults in upper reaches suggest that distribution of subadults or adults requires extensive upstream movements. To date, these movements have not been documented and factors associated with such movements are poorly understood.

Our primary objectives were to describe the distribution of subadults and adults in the Colorado River, document their dispersal patterns, and attempt to explain what motivates such dispersal. We hypothesized that upstream movement of young adults is a response to resource gradients. More specifically, we hypothesized that upstream dispersal results from individuals seeking foraging areas more likely to meet the changing food requirements of a growing piscivore, and we investigated spatial variation in Colorado squawfish body condition and abundance of likely forage species. Longitudinal temperature gradients were also examined and related to the distribution of adults.

\section{Methods}

Study area.-The study area included the occupied range of the Colorado squawfish in the Colorado River, from the confluence with the Green River in Utah upstream to the Grand Valley diversion dam at Palisade, Colorado (the latter is a barrier to upstream movement; Figure 1). Also included was the lowermost $3.5 \mathrm{~km}$ of the Gunnison River, from the confluence with the Colorado River upstream to the Redlands diversion dam (also a barrier to upstream movement). Locations are in river kilometers (rkm) from the Green River confluence (rkm 0.0), converted from river miles as mapped by Belknap and Belknap (1974). The study area (Figure 1) was partitioned into a lower reach that extended from rkm 0.0 upstream to the lower end of Westwater Canyon (rkm 181.0) and an upper reach from the upper end of Westwater Canyon (rkm 200.0) upstream to the Grand Valley diversion dam (rkm 298.1). Westwater Canyon, a 
TABLE 1.-Locations of study strata and subreaches sampled for potential Colorado squawfish food fishes. Locations are described in river kilometers (rkm) upstream of the confluence of the Green River. Stratum 4 was not sampled (see text).

\begin{tabular}{ccccc}
\hline Stratum & $\begin{array}{c}\text { Mean } \\
\text { gradient } \\
(\mathrm{m} / \mathrm{km})\end{array}$ & $\begin{array}{c}\text { Strata } \\
\text { location } \\
(\mathrm{rkm})\end{array}$ & Subreach & $\begin{array}{c}\text { Subreach } \\
\text { location } \\
(\mathrm{rkm})\end{array}$ \\
\hline 1 & 0.21 & $0.0-112.6$ & 1 & $5.2-6.0$ \\
& & & 2 & $12.2-13.0$ \\
& & & 3 & $20.9-21.7$ \\
& & & 5 & $30.1-30.9$ \\
& & & 6 & $61.6-62.4$ \\
& & & 7 & $100.6-101.4$ \\
2 & 1.33 & $112.6-140.6$ & 8 & $121.3-122.1$ \\
& & & 9 & $129.0-129.8$ \\
3 & 0.61 & $140.6-181.0$ & 10 & $148.5-149.3$ \\
& & & 11 & $156.6-157.4$ \\
& & & 12 & $172.2-173.0$ \\
4 & 2.42 & $181.0-200.0$ & & \\
5 & 0.91 & $200.0-245.5$ & 13 & $212.9-213.7$ \\
& & & 14 & $228.0-228.8$ \\
& & & 15 & $234.6-235.4$ \\
6 & 1.27 & $245.5-275.1$ & 16 & $252.9-253.7$ \\
& & & 17 & $270.0-270.8$ \\
7 & 1.70 & $275.1-298.1$ & 18 & $287.2-288.0$ \\
& & & 19 & $293.8-294.6$ \\
\hline
\end{tabular}

19-km section dominated by large rapids and turbulent eddies, was excluded for logistical reasons and because few Colorado squawfish were found there in past studies (McAda and Kaeding 1991). The river was divided into seven strata based on major changes in average channel gradient (Table 1): three downstream (strata 1-3) and three upstream (strata 5-7) of Westwater Canyon (stratum $4)$.

Distribution and movement.-We documented distribution of Colorado squawfish by systematically sampling the study area from mid-April through mid-June for 1991-1994. Trammel nets were set in backwaters, flooded ponds, and flooded canyon mouths because Colorado squawfish are attracted to calm habitats during the spring runoff period (Osmundson and Kaeding 1989). Capture techniques are described in detail in Osmundson and Burnham (1998). Three sampling passes (7$9 \mathrm{~d}$ each) through the upper reach were made each spring, and every zero- or low-velocity habitat large enough to contain adult Colorado squawfish was netted. Similar preliminary data collected during spring 1990 were also used. In the lower reach, one pass was made in 1991 and two passes were made each spring during 1992-1994. In some portions of both reaches where zero-velocity habitats were rare, shorelines were electrofished with a 5$\mathrm{m}$, electrofishing boat equipped with a Coffelt
VVP-15 electrofisher (Coffelt Manufacturing, Flagstaff, Arizona) that produced pulsed DC.

Captured Colorado squawfish were anesthetized with tricaine methanesulfonate and scanned for the presence of a passive integrated transponder (PIT) tag (Biomark, Inc., Boise, Idaho); if no tag was detected, one was implanted (see Osmundson and Burnham 1998). Fish were measured (nearest 1 $\mathrm{mm}$ ) for maximum total length (TL; Anderson and Gutreuter 1983), weighed with an electronic balance (nearest $1 \mathrm{~g}$ ), and released after recovery from the anesthetic.

Netting catch per unit effort (CPUE) was used to assess river-wide differences in relative abundance of adult Colorado squawfish. However, because differences in fish density among river strata may have been influenced by the number of backwaters available for use by fish (higher concentrations could occur in strata with few backwaters), we pooled netting data by reach for between-reach comparisons rather than attempt to compare densities among river strata.

To measure movement, we compared locations of consecutive captures of marked individuals. Movement patterns were compared among 100$\mathrm{mm}$ length-classes and between fish initially captured in the lower reach and fish initially captured in the upper reach. Localized movements were considered to be those less than $10 \mathrm{~km}$ and were not analyzed. For assessing movement, we considered only consecutive captures at least 1 year apart to allow fish adequate time to disperse between captures. Also, captures during spawning periods and during pre- and postspawning migratory periods were excluded so that temporary spawning movements would not be confused with dispersal movements. Since concurrent radiotelemetry studies indicated that annual spawning movements did not commence until late June or later, only samples through 16 June were considered (except in 1994, when spawning movements began early and all June samples were excluded). Additional capture data collected during 19911995 by the Colorado Division of Wildlife (from stratum 5) and the Utah Division of Wildlife Resources (from portions of strata 1 and 3 ) were also used in the movement analysis (both agencies conduct annual spring electrofishing surveys). Records from a 1994-1995 U.S. Fish and Wildlife Service (USFWS) survey of the lower $3.5 \mathrm{~km}$ of the Gunnison River and a 1995 survey of flooded ponds near rkm 262 were also used.

Body condition.- - Relative body condition (Le Cren 1951) was calculated for Colorado squawfish 
$200 \mathrm{~mm}$ TL and longer. Because condition changes monthly (Hawkins 1992), month-specific lengthweight relationships were developed by using the 1990-1994 data. Only fishes weighed with an electronic balance were included. Excluded from the June calculations were 1994 data because we assumed gonads matured early that year and would have biased fish weights. Relative condition of each fish was calculated using the month-specific constants from the length-weight relationships (fish not weighed with a balance and those captured in June 1994 were again excluded). We compared mean condition factors between upper and lower reaches within 100-mm length-classes and among length-classes within reaches.

Relative abundance of potential forage species.-Estimates of relative abundance of small prey fish less than $100 \mathrm{~mm}$ TL were from unpublished fall seine survey data collected for an interagency annual monitoring program (see McAda et al. 1994 for methods). We used electrofishing and trammel netting to develop catch-rate indices of larger prey fish (>100 mm TL) likely to serve as forage for large Colorado squawfish. Electrofishing surveys were conducted from 20 April through 7 July, 1993, in two or more $0.8-\mathrm{km}$ subreaches within each stratum (Table 1). The starting points (rkm) for electrofishing subreaches were selected by using a random numbers table. Within each sample subreach, both shorelines were electrofished in a downstream direction. After identification and length measurement, fish were released at the lower end of the subreach. Catch per unit effort was expressed as the number caught divided by the time electric current was applied, as metered by the VVP-15. Numbers of each species captured in trammel nets during Colorado squawfish sampling were recorded during 1992 1994, and CPUE was calculated as the mean number of fish caught per net set.

We developed an index of relative abundance for soft-rayed fusiform fish by pooling CPUE of the common species within each stratum. Spined species were excluded, as were rare species. Though prey preference of Colorado squawfish is unknown, soft-rayed fish were assumed to be preferred over spined or spiny-rayed fish, as is the case with northern pike Esox lucius and muskellunge E. masquinongy (Beyerle and Williams 1968; Mauck and Coble 1971; Wahl and Stein 1988). These two large, cool-to-warmwater, north temperate piscivores have morphologies and ecological roles similar to Colorado squawfish. Spined and spiny-rayed fish are more costly, in terms of both energy required for ingestion and risk of mortality from throat or stomach puncture (Gillen et al. 1981; McAda 1983). We conducted an additional relative abundance analysis by first partitioning potential prey so that only soft-rayed fish 100-300 mm long were considered, based on the assumption that Colorado squawfish can only consume fish up to about half their own length (e.g., Juanes 1994).

Diet.-Stomach contents of Colorado squawfish captured during 1994 were examined by using a Seaburg stomach sampler (Seaburg 1957) as modified by Gengerke et al. (1973). Back-flush tubes of various diameters were used based on the size of the fish. Empty stomachs were recorded in the field. Stomach contents from those fish containing food were preserved in $10 \%$ formalin and sent to the Larval Fish Laboratory (LFL) at Colorado State University for analysis. Food items were identified to lowest practical taxon and measured in standard length (SL), when possible; visual estimates were made of the percentage of total volume of stomach contents contributed by each taxon. The 'aggregate percent method' (Swanson et al. 1974) was used to calculate an overall percent volume for each food item for those fish containing food.

Temperature.-Main channel temperatures (nearest $0.1^{\circ} \mathrm{C}$ ) were monitored at sites within strata $1,3,5,6$, and 7 and at two sites upstream of stratum 7 (Cameo and Rulison, Colorado) in a reach historically used by Colorado squawfish but presently unoccupied due to the long-term effects of three instream barriers that block migrations (Figure 1). At five sites, thermographs (Ryan Instruments, Redmond, Washington) were deployed and downloaded twice yearly. Data from stratum 5 and Cameo were collected by the U.S. Geological Survey at the Colorado-Utah state line and Cameo gauging stations, respectively. Mean daily values were calculated from readings taken every $2 \mathrm{~h}$.

We compared temperature indices for growth among thermograph sites for the 1992-1996 period to measure spatial variation in thermal regime suitability along the river continuum. We derived these indices by using an approach developed specifically for Colorado squawfish by Kaeding and Osmundson (1988) in which mean daily temperatures are converted to values relative to the maximum potential (1.0) for growth at the optimum temperature $\left(25^{\circ} \mathrm{C}\right)$; these thermal units are then summed to provide an annual value. 


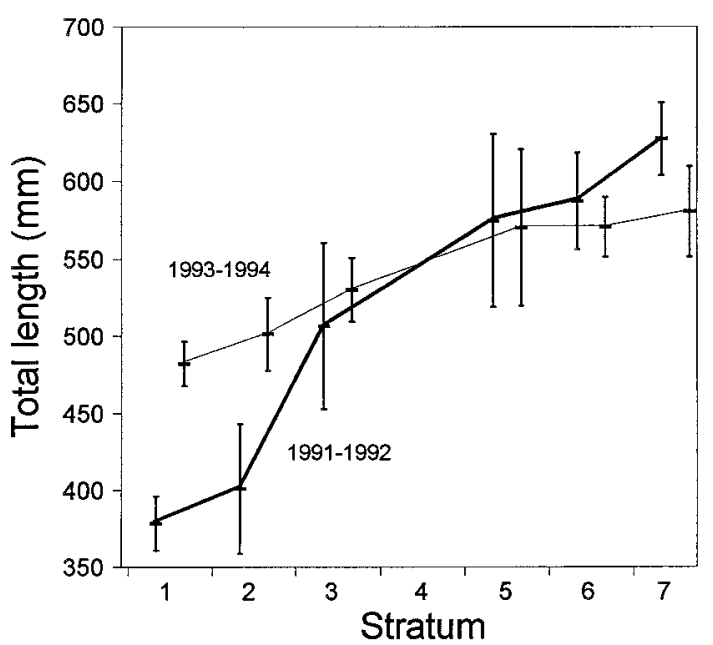

Figure 2.-Mean length of Colorado squawfish by stratum. Lengths of fish captured in 1991 and 1992 (heavy line) and those captured in 1993 and 1994 (light line) were pooled. Error bars represent $95 \%$ confidence intervals.

\section{Results}

\section{Distribution}

Mean length of Colorado squawfish captured in this study progressively increased upstream (Figure 2). Because samples from strata 2, 3, and 5 were small, lengths of fish captured were pooled into 1991-1992 and 1993-1994 periods for statistical tests. Analysis of variance (ANOVA) revealed that for 1991-1992 data, mean lengths in strata 3,5,6, and 7 differed significantly from the mean in stratum 1 ; those in strata 5-7 differed from the mean in stratum 2; mean lengths in strata 7 and 3 also differed ((ANOVA, Tukey-Kramer multiple comparison; $P<0.05)$. Regression indicated significant relationships (Figure 3) between total length and rkm in $1991\left(r^{2}=0.59, P\right.$ $<0.0001)$ and $1992\left(r^{2}=0.60, P<0.0001\right)$; slopes between 1991 and 1992 were not significantly different $(P=0.28)$.

For 1993-1994, differences in mean lengths among strata were not as pronounced as in 19911992. Significant differences were found only between stratum 1 and strata 3, 5, 6, and 7 (ANOVA, Tukey-Kramer multiple comparison, $P<0.05$ ). Mean lengths in the two most downstream strata were significantly greater during 1993-1994 than during 1991-1992 ( $t$-test, $P<0.0001)$. In the upper reach, mean lengths declined from 1991-1992 to 1993-1994 (significantly only in stratum 7; $t$-test, $P=0.012$ ). Regression indicated significant relationships between total length and rkm loca-

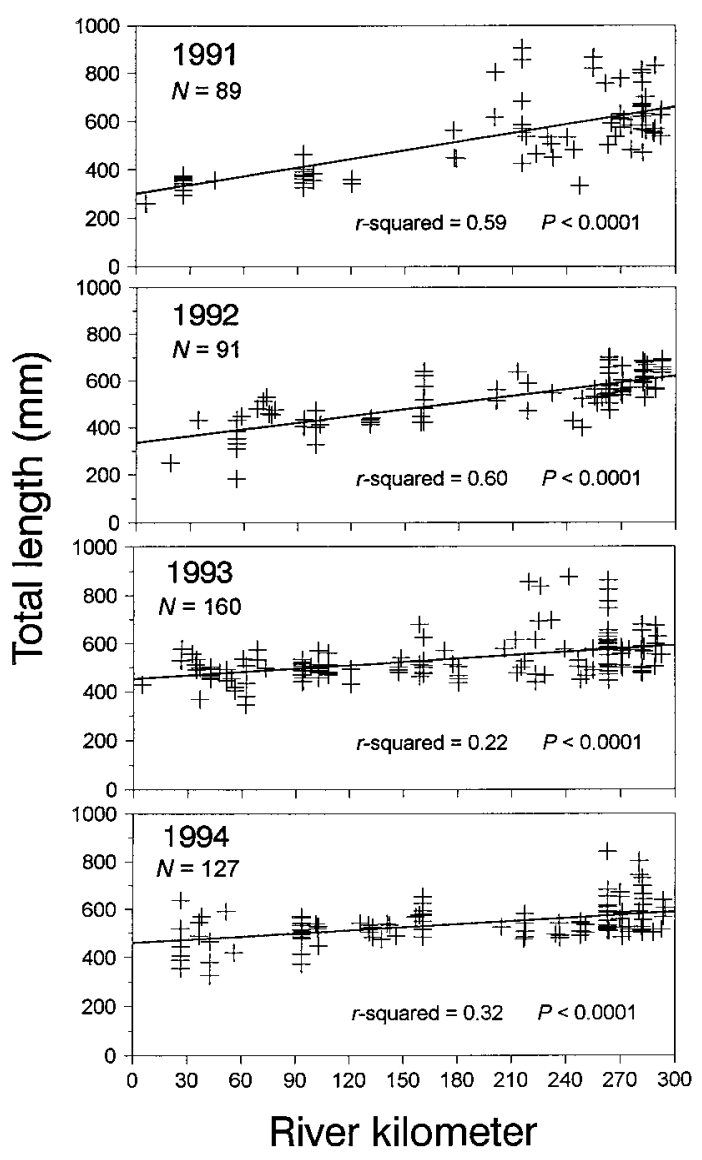

FiguRE 3.-Relationship between Colorado squawfish length and kilometers upstream from the lower end of the study area (river kilometer 0 at the Green River confluence) during 1991-1994.

tion in $1993\left(r^{2}=0.22, P<0.0001\right)$ and $1994\left(r^{2}\right.$ $=0.32, P<0.0001)$. Slopes were not significantly different between 1993 and $1994(P=0.13)$, but both differed from slopes of relationships for 1991 and 1992 (all $P<0.003$ ).

Netting catch rates indicated that adult distribution changed during 1991-1994. During 19911992, very few adult Colorado squawfish were caught in the lower reach. In 1991, Colorado squawfish $500 \mathrm{~mm}$ and longer were captured only in stratum 3 (one fish) and none in strata 1 or 2 , resulting in an overall mean CPUE in the lower reach of 0.02 fish $(\geq 500 \mathrm{~mm})$ per net $(\mathrm{SE}=0.02$; $N=47$ net sets). In contrast, 42 fish $500 \mathrm{~mm}$ or longer were captured with nets in the upper reach, for a mean CPUE of 0.30 ( $\mathrm{SE}=0.07 ; N=139$ ). A similar pattern was evident in 1992: Colorado squawfish $500 \mathrm{~mm}$ or longer were captured only in stratum 3 (six fish) and none in strata 1 or 2. 


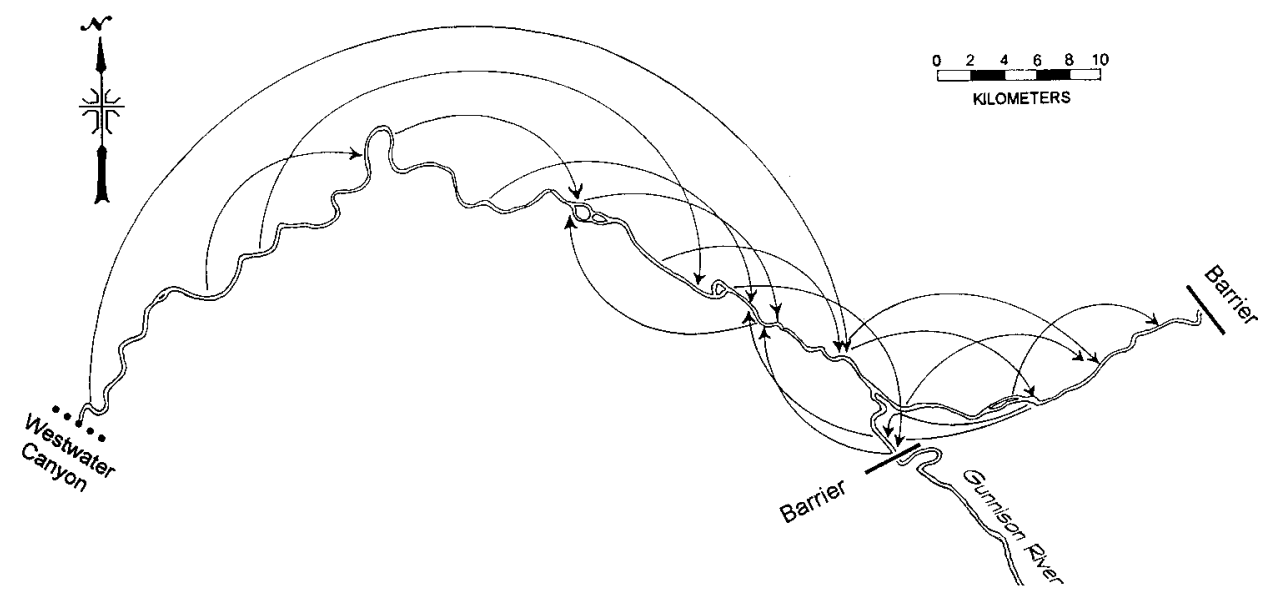

Figure 4.- Movement of Colorado squawfish PIT-tagged in the upper reach of the Colorado River. Arrow origins represent capture location; arrow points represent location of next capture. Consecutive captures were at least 1 year apart; only movements greater than $10 \mathrm{~km}$ are shown.

Mean CPUE of adults $500 \mathrm{~mm}$ and longer was $0.13(\mathrm{SE}=0.09 ; N=49)$ in the lower reach and $0.46(\mathrm{SE}=0.09 ; N=114)$ in the upper reach.

By 1993, adult demographics were quite different. Adult Colorado squawfish $500 \mathrm{~mm}$ and longer were captured in stratum 1 (17 fish) and stratum 2 (2 fish) for the first time during the study, and CPUE of individuals $500 \mathrm{~mm}$ and longer increased to 0.20 per net $(\mathrm{SE}=0.04 ; N=115$ net sets $)$. In the upper reach, 1993 CPUE of adults was 0.57 $(\mathrm{SE}=0.10 ; N=115)$. In 1994, catch rates were generally similar to those of 1993 in both reaches. This increase in adult CPUE from 1991 to 1993 coincided with the recruitment of 2-3 strong yearclasses produced during the mid-1980s (see Osmundson and Burnham 1998).

\section{Movements}

Of Colorado squawfish initially captured and tagged in the upper reach, 69 were recaptured at least once in a subsequent year, and some were recaptured in two or more subsequent years. Including multiple captures of the same fish, there were 92 recaptures during 1991-1995. Of these, $16(17 \%)$ were located farther than $10 \mathrm{~km}$ from the previous capture site. Twelve of these 16 displacements were directed upstream (Figure 4), three were directed downstream, and one was directed both downstream and upstream (this fish moved down the Colorado River and up the lower Gunnison River). Of movements entirely within the Colorado River, the portion of displacements directed upstream was higher (test of proportions, $P=0.0098)$ than predicted if direction was ran- dom (50\%), though mean distance moved upstream was not significantly different than that moved downstream $(P=0.359)$. None of the fish captured in the upper reach during the study period was later recaptured in the lower reach.

Of fish initially captured in the lower reach, 37 were recaptured in one or more subsequent years, totaling 43 recaptures during 1992-1995. Of the 43 recaptures, $25(58 \%)$ were located farther than $10 \mathrm{~km}$ from the previous capture site. Seventeen $(68 \%)$ of these long-distance displacements were directed upstream (Figure 5); this proportion was not significantly different than if direction was random $(P=0.086)$. However, when data from those moving more than $25 \mathrm{~km}(N=23)$ were analyzed, the percent of fish having moved upstream $(74 \%)$ was significantly different than $50 \%(P=0.037)$. Also, the mean distance of movements $(>10 \mathrm{~km})$ directed upstream $(108.2 \mathrm{~km}, \mathrm{SE}=16.5)$ was significantly greater ( $t$-test, $P=0.0005)$ than the mean distance of those directed downstream (35.1 $\mathrm{km}, \mathrm{SE}=6.9$ ).

Many fish captured in the lower reach were later recaptured in the upper reach sometime during the 5-year period: 11 of 25 movements farther than 10 $\mathrm{km}(44 \%)$ were from the lower reach to the upper reach. Though sample sizes were small and sample efforts in 1995 were different from those during 1991-1994, the proportion of fish initially captured in the lower reach and recaptured in the upper reach increased from 1992 through 1995. In 1992, no recaptures of lower-reach fish occurred in the upper reach (0 of 1 recapture); in 1993, 2 of 14 such recaptures $(14 \%)$ occurred in the upper reach; 


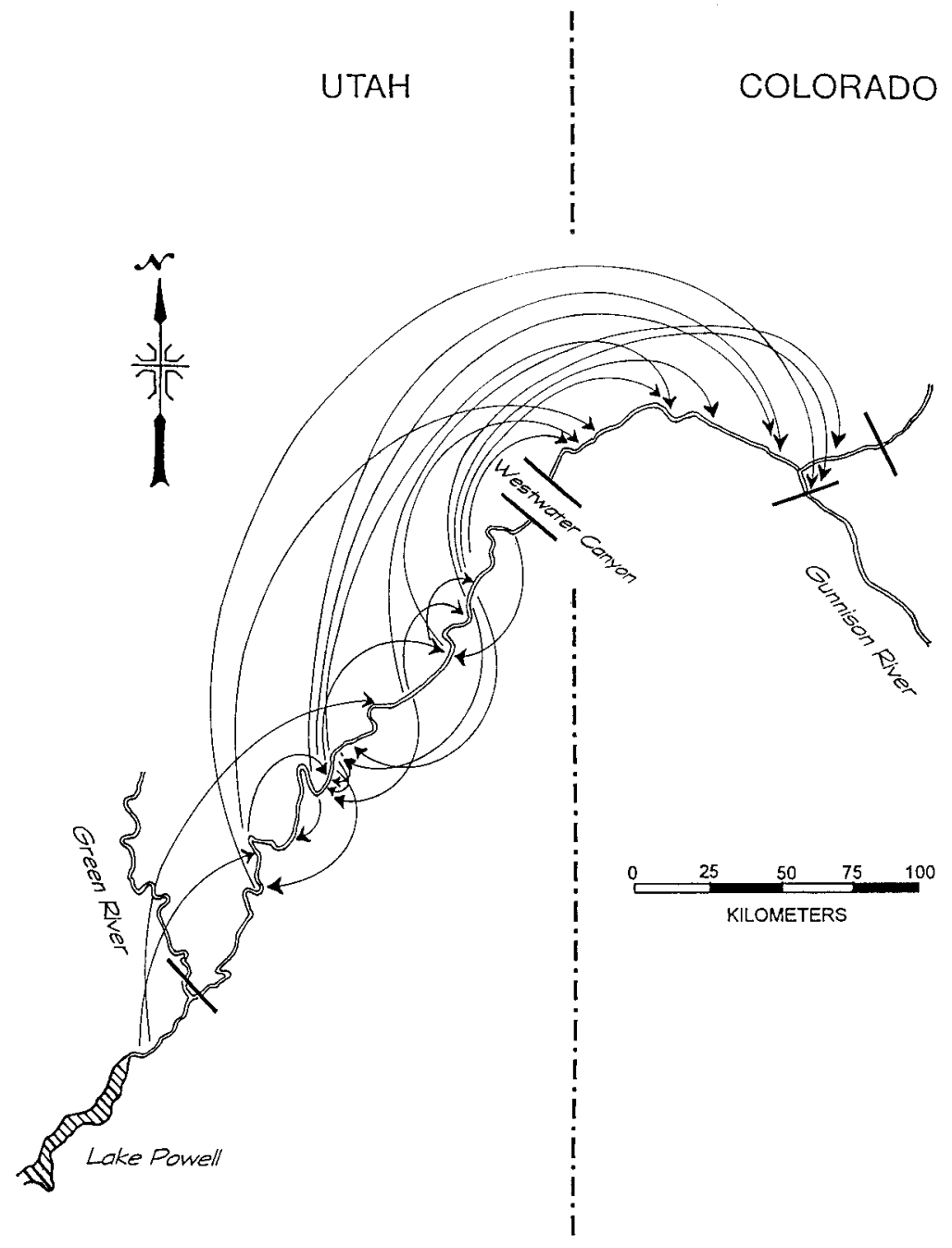

FIGURE 5.-Movement of Colorado squawfish PIT-tagged in the lower reach of the Colorado River. Arrow origins represent capture location; arrow points represent location of next capture. Consecutive captures were at least 1 year apart; only movements greater than $10 \mathrm{~km}$ are shown.

TABLE 2.-Total lengths of Colorado squawfish before and after movement from the lower reach to the upper reach of the upper Colorado River. Only those fish moving between reaches based on capture-recapture in consecutive years are included; $\mathrm{Rkm}$ = river kilometer location.

\begin{tabular}{|c|c|c|c|c|c|c|}
\hline \multirow[b]{2}{*}{$\begin{array}{c}\text { Fish } \\
\text { number }\end{array}$} & \multicolumn{3}{|c|}{ Lower reach capture } & \multicolumn{3}{|c|}{ Upper reach capture } \\
\hline & Year & $\mathrm{Rkm}$ & $\begin{array}{l}\text { Length } \\
(\mathrm{mm})\end{array}$ & Year & $\mathrm{Rkm}$ & $\begin{array}{c}\text { Length } \\
\text { (mm) }\end{array}$ \\
\hline 129 & 92 & 81.5 & 438 & 93 & 175.2 & 478 \\
\hline 131 & 94 & 96.2 & 535 & 95 & 132.0 & 580 \\
\hline 186 & 92 & 98.9 & 421 & 93 & 154.3 & 449 \\
\hline 238 & 93 & 58.2 & 523 & 94 & 147.1 & 539 \\
\hline 323 & 93 & 26.5 & 456 & 94 & GU-1.1 ${ }^{\mathrm{a}}$ & 466 \\
\hline $\mathrm{C}-1$ & 94 & 97.6 & 555 & 95 & 147.5 & 577 \\
\hline
\end{tabular}

${ }^{\mathrm{a}} \mathrm{GU}=$ Gunnison River. in 1994,5 of $16(31 \%)$ occurred in the upper reach; in 1995,5 of $12(42 \%)$ occurred in the upper reach.

It was difficult to ascertain a minimum size for Colorado squawfish moving from the lower to the upper reach because recaptures were often 2 years or more apart. Only six lower-to-upper-reach recaptures were 1 year apart. The smallest of these fish was between 421 and $449 \mathrm{~mm}$ when it moved; the largest was between 555 and $577 \mathrm{~mm}$ (Table $2)$. For fish with greater recapture intervals, the largest fish was between 570 and $628 \mathrm{~mm}$ when it moved to the upper reach sometime during a 2.5-year period.

Distance moved between captures was inversely 
TABLE 3.-Length-weight regression coefficients (SEs in parentheses) used in calculation of relative condition of Colorado squawfish captured from the Colorado River during 1990-1994. Relative condition $\left(K_{n}\right)$ was expressed as $K_{n}=100 \times M_{o} / M_{e}$, where $M_{o}$ is the observed mass (g) and $M_{e}$ is the expected mass $(\mathrm{g})$ as calculated from $\log _{10} M_{e}=\log _{10}$ (length) $\cdot m+b$. Length is measured in millimeters.

\begin{tabular}{lrccc}
\hline Month & \multicolumn{1}{c}{$N$} & Slope $(m)$ & $y$-Intercept $(b)$ & $R^{2}$ \\
\hline Apr & 81 & $3.17326(0.061)$ & $-5.54824(0.167)$ & 0.972 \\
May & 257 & $3.25981(0.030)$ & $-5.77281(0.083)$ & 0.978 \\
Jun & 128 & $3.20661(0.038)$ & $-5.60323(0.010)$ & 0.983 \\
\hline
\end{tabular}

related to fish size. Mean displacement between consecutive captures was $43.8 \mathrm{~km}(\mathrm{SE}=15.5 ; \mathrm{N}$ $=17$ ) for Colorado squawfish less than $500 \mathrm{~mm}$ (at time of second capture), $13.3 \mathrm{~km}$ ( $\mathrm{SE}=3.5$; $N=68$ ) for fish 500-599 mm (between first and second captures $)$, and $3.1 \mathrm{~km}(\mathrm{SE}=0.8 ; N=34)$ for fish $600 \mathrm{~mm}$ and longer (at first capture). Mean displacement was not significantly different between fish 500-599 $\mathrm{mm}$ and those $600 \mathrm{~mm}$ and longer, but displacements for both groups were significantly less than for fish smaller than $500 \mathrm{~mm}$ (ANOVA, Tukey-Kramer multiple comparison, $P$ $<0.05)$. Also, mean displacement of fish $550 \mathrm{~mm}$ and longer $(7.5 \mathrm{~km} ; \mathrm{SE}=2.5 ; N=70)$ was significantly less ( $t$-test, $P=0.008)$ than that of fish smaller than $550 \mathrm{~mm}(33.6 \mathrm{~km} ; \mathrm{SE}=10.2 ; N=$ $30)$. The proportion of total displacements consisting of long-distance displacements $(>10 \mathrm{~km})$ was significantly different between all size-groups (test of proportions, all $P<0.003$ ) and was inversely related to length: for fish smaller than 500 $\mathrm{mm}, 59 \%$ of displacements were farther than 10 $\mathrm{km}$; for fish 500-599 mm long, 28\%; and for fish $600 \mathrm{~mm}$ and longer, $6 \%$ were long distance.

\section{Body Condition}

Mean relative body condition $\left(K_{n}\right)$ of Colorado squawfish varied with river reach and fish lengthclass (month-specific constants are shown in Table $3)$. In the lower reach, fish condition declined with increasing length (Figure 6): mean condition factors of fish 500-599 and 600-699 mm were significantly lower (ANOVA, Tukey-Kramer multiple comparison, $P<0.05$ ) than those of fish 200 299, 300-399, or 400-499 mm. Also, mean $K_{n}$ of fish 400-499 $\mathrm{mm}$ was significantly lower than that of fish 300-399 mm $(P<0.05)$. In contrast, body condition of upper-reach fish increased with fish length, and mean $K_{n}$ was highest in fish 700-799 $\mathrm{mm}$. Mean $K_{n}$ of fish $600-699 \mathrm{~mm}$ was significantly higher than those of fish $400-499$ or 500-

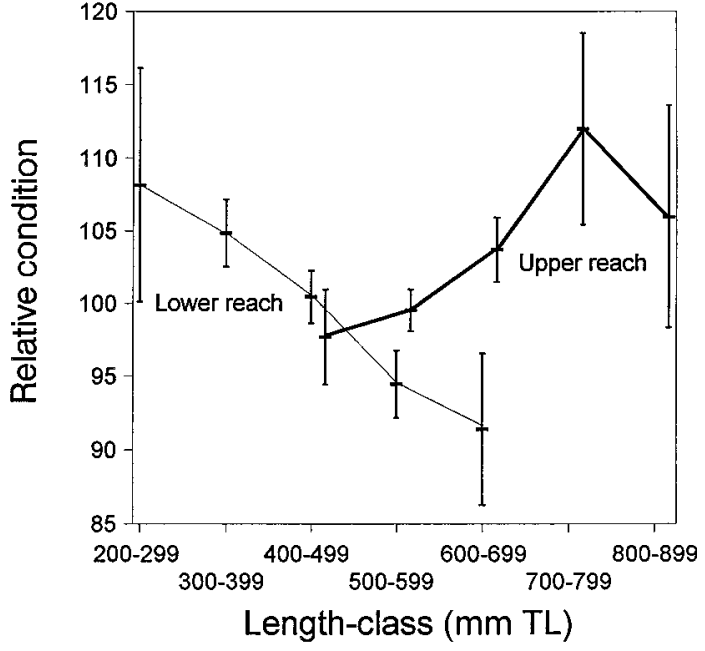

FIGURE 6.-Mean relative condition $\left(K_{n}\right)$ of Colorado squawfish by length-class and Colorado River reach. Error bars represent $95 \%$ confidence intervals.

$599 \mathrm{~mm}$, and mean $K_{n}$ of fish $700-799 \mathrm{~mm}$ was significantly higher than that of fish $600-699 \mathrm{~mm}$ $(P<0.05)$.

Mean $K_{n}$ began to differ between reaches once fish attained 500-599 mm. However, reach comparisons could not be made for all length-classes because no fish 200-299 mm and only two 300399-mm fish were captured in the upper reach, and in the lower reach, no fish $700 \mathrm{~mm}$ or larger was captured. Significant differences were detected between reaches within length-classes of 500-599 and 600-699 mm ( $t$-test, $P<0.0004$ for both), but not for fish 400-499 mm long $(P=0.14)$.

\section{Relative Abundance of Forage Fish}

Small fish $(<100 \mathrm{~mm})$ densities in backwaters were generally higher in the lower reach than in the upper reach: mean annual CPUE (fish per area seined) during fall surveys (1991-1995) was 5.7/ $\mathrm{m}^{2}(\mathrm{SE}=0.4)$ in the lower reach and $3.3 / \mathrm{m}^{2}(\mathrm{SE}$ $=0.4$ ) in the upper reach. Results from ANOVA and multiple comparison (obtained by using logtransformed data) indicated that the difference for the 5-year period was significant (ANOVA, $P<$ 0.0000001 ); however, within years, the only significant difference was in 1994 (Tukey-Kramer multiple comparison, $P<0.05)$. Three introduced species, red shiner Cyprinella lutrensis, fathead minnow Pimephales promelas, and sand shiner $\mathrm{No}$ tropis stramineus, together made up $84-99 \%$ of all fish within annual reach samples. Though fish densities within backwaters were lower in the upper 
reach, greater backwater area per unit length of river existed there, averaging $0.18 \mathrm{ha} / \mathrm{km}$, than in the lower reach, where backwater area averaged $0.06 \mathrm{ha} / \mathrm{km}$ (C. McAda, USFWS, unpublished data). Hence, overall abundance of small forage fish in the two reaches may have been more similar than indicated by CPUE data alone.

Catch rates of larger fusiform, soft-rayed fish were generally higher in the upper reach than in the lower reach, with highest catch rates occurring in the uppermost stratum. Those fish $100 \mathrm{~mm}$ and longer included native roundtail chub Gila robusta, bluehead suckers Catostomus discobolus, flannelmouth suckers $C$. latipinnis, nonnative white suckers Catostomus commersoni, and various sucker hybrids. Common nonnative species susceptible to the two gear types but considered largely invulnerable to predation were the deep-bodied common carp Cyprinus carpio and the spined channel catfish Ictalurus punctatus and black bullhead Ameiurus melas.

Electrofishing catch rate of fusiform-shaped fish $100 \mathrm{~mm}$ and longer was higher in stratum 3 than in stratum $1(P<0.05)$, but CPUE in stratum 3 was not significantly higher than in stratum 2 . Catch rates in upper-reach strata were each higher (ANOVA, Tukey-Kramer multiple comparison, $P$ $<0.05$ ) than in all lower-reach strata (Figure 7). Among upper-reach strata, the catch rate in stratum 7 was higher than in strata 5 and $6(P<0.05)$, and no significant difference was detected between strata 5 and 6. For all fish 100-300 mm (excluding ictalurids), mean electrofishing CPUE was significantly higher in each upper-reach stratum than in any lower-reach stratum $(P<0.05)$, though no differences in CPUE were found among strata within either reach.

Trammel-netting CPUE of fusiform-shaped fish displayed a trend similar to electrofishing with rates generally higher in upstream strata. Catch rates were not significantly different among years within any lower-reach stratum nor among lowerreach strata within years (ANOVA, Tukey-Kramer multiple comparison, $P>0.05)$. The CPUE in stratum 5 was significantly higher $(P<0.05)$ than that in stratum 1 during 1992 and 1994 and higher than stratum 3 CPUE in 1994. In stratum 6, CPUE was significantly higher than in stratum 1 in all years, higher than in stratum 3 in 1993 and 1994, and higher than in stratum 5 in 1993. In stratum 7, CPUE was significantly higher than in all other strata except stratum 6 in 1993. When all three years were considered, CPUE in stratum 7 was
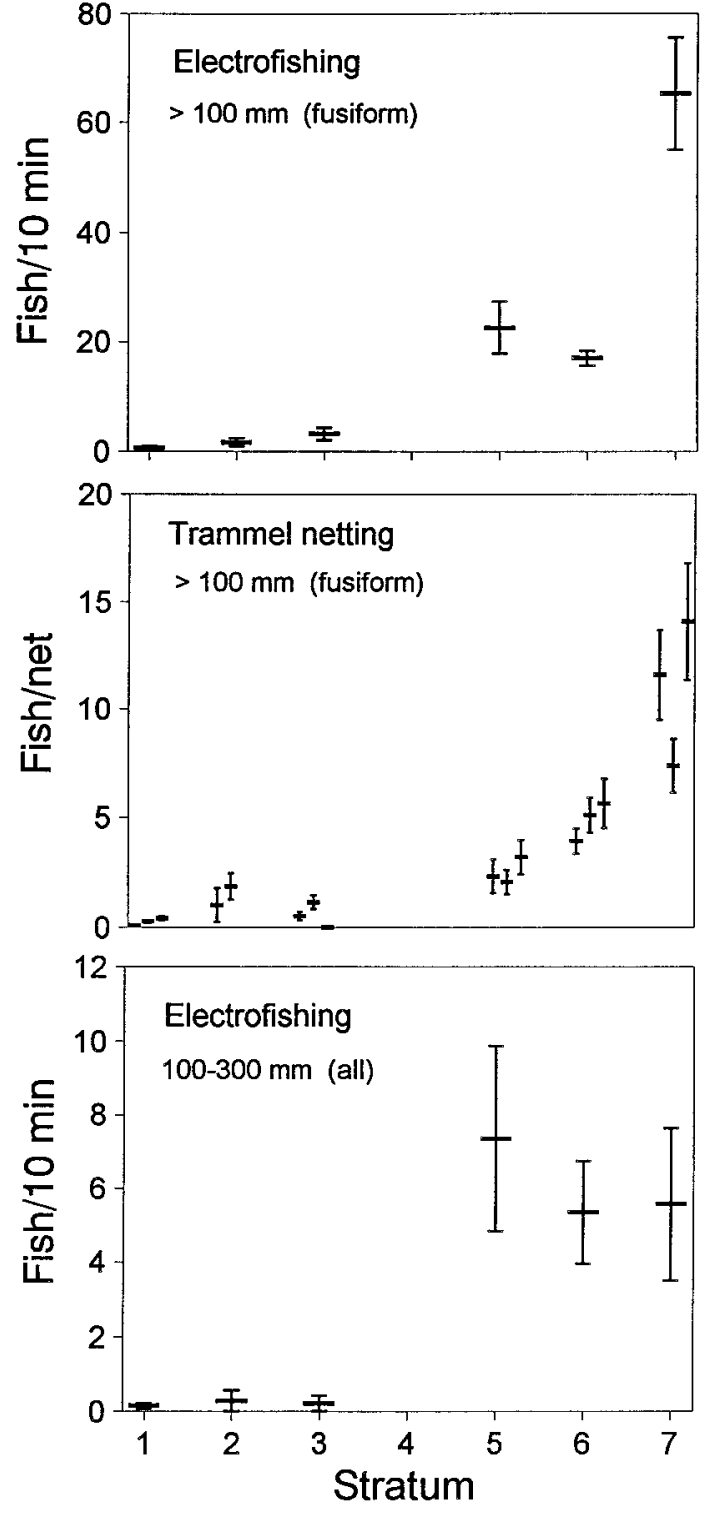

FIGURE 7.-Electrofishing and trammel-netting catch per unit effort (CPUE) by stratum for potential forage fishes of large Colorado squawfish. Electrofishing (top) and trammel netting (middle) catches of fusiform fish more than $100 \mathrm{~mm}$ in total length include roundtail chub, flannelmouth sucker, bluehead sucker, white sucker, and sucker hybrids. Electrofishing CPUE of fish $100-300 \mathrm{~mm}$ (bottom) includes all species except channel catfish and black bullhead. For trammel netting, separate bars within each stratum represent CPUE from (left to right) 1992, 1993, and 1994 (no 1994 data in stratum 2); electrofishing was conducted in 1993 only. Vertical lines are \pm SE of the geometric mean. 
TABLE 4.-Diets of Colorado squawfish (400-550 mm total length) during spring 1994. Values are overall volumes of each food item as a percentage of total volume $(100 \%)$ and are averages from all fish containing food (see text); UI = unidentified; MOD = miscellaneous organic debris.

\begin{tabular}{|c|c|c|c|c|}
\hline \multirow[b]{3}{*}{ Component } & \multirow{2}{*}{\multicolumn{2}{|c|}{ Reach }} & \multicolumn{2}{|c|}{ Habitat } \\
\hline & & & \multirow{2}{*}{$\begin{array}{c}\text { Back- } \\
\text { waters } \\
(N=30)\end{array}$} & \multirow[b]{2}{*}{$\begin{array}{l}\text { Channel } \\
(N=9)\end{array}$} \\
\hline & $\begin{array}{c}\text { Lower } \\
(N=16)(\end{array}$ & $\begin{array}{c}\text { Upper } \\
(N=17)\end{array}$ & & \\
\hline UI fish parts & 23.6 & 35.8 & 30.2 & 20.8 \\
\hline UI fish & 24.5 & 2.9 & 11.5 & 11.5 \\
\hline Fathead minnow & 27.2 & 28.2 & 35.3 & 27.6 \\
\hline Red shiner & 0.0 & 11.1 & 6.8 & 0.0 \\
\hline Sand shiner & 13.7 & 0.0 & 1.3 & 25.1 \\
\hline Roundtail chub & 9.3 & 0.0 & 3.3 & 5.8 \\
\hline \multicolumn{5}{|l|}{ Green sunfish } \\
\hline Lepomis cyanellus & 0.0 & 5.8 & 3.3 & 0.0 \\
\hline White sucker & 0.0 & 10.9 & 6.2 & 0.0 \\
\hline Annelids & 0.9 & 0.7 & 1.0 & 0.7 \\
\hline MOD & 0.8 & 4.5 & 1.0 & 8.6 \\
\hline
\end{tabular}

significantly higher than in all other strata, and stratum 6 CPUE was higher than that in stratum 5.

Diet

The modified Seaburg stomach sampler proved effective in removing stomach contents from Colorado squawfish smaller than about $550 \mathrm{~mm}$. For larger adults, the method was abandoned due to persistent difficulties associated with (1) handling the fish while attempting to manipulate the flushing tube, (2) passing tubes of sufficient length and diameter (to encapsulate large prey) down the esophagus, and (3) producing sufficient flushing pressure with the squeeze bulb for forcing items through the large tubes. Efforts to encourage large fish to regurgitate their stomach contents by using tartar emetic (after Jernejcic 1969) were also abandoned because of apparent stress to the fish.

Diets of Colorado squawfish 400-550 mm captured in the upper reach were similar to those of fish captured in the lower reach and were similar between fish captured from main channel and backwater habitats (Table 4). Fish in stomach samples were generally small: lengths of fathead minnows, the most common prey, averaged $51 \mathrm{~mm}$ (SL) whereas roundtail chub and white sucker averaged 85 and $70 \mathrm{~mm}$ (SL), respectively. Of stomachs containing identifiable fish $(N=27), 63 \%$ contained one fish; $26 \%$ contained two or three fish; $4 \%$ contained five fish; and $7 \%$ contained six or seven fish. Feeding rate may be reduced in this species prior to spawning: significantly more (test of proportions, $P=0.002$ ) sampled fish 400-550 mm (TL) had empty stomachs from 26 May to 20 June $(93 \%, N=14)$ than fish sampled before 26 May $(41 \%, N=58)$ in the early spawning year of 1994. Percentages of empty stomachs before 26 May were similar $(P>0.05)$ between lower (38\%, $N=26)$ and upper reaches $(44 \%, N=32)$.

\section{Temperature}

Annual thermal units for growth decreased in an upstream direction as expected (Table 5). As a percentage of thermal units in stratum 1 , thermal units in stratum 3 were 93\%; in stratum 5, 81\%, in stratum 6,71\%; in stratum 7,62\%; at Cameo, 54\%; and at Rulison, 42\%. Thermal units decreased between sites in strata 1 and 3 by an average of 0.08 units/rkm; between strata 3 and 5 sites by $0.17 / \mathrm{rkm}$; between strata 5 and 6 sites by $0.15 / \mathrm{rkm}$; between strata 6 and 7 sites by 0.23 / rkm; between stratum 7 and Cameo sites by 0.24 /

TABLE 5.- Total annual thermal units for Colorado squawfish growth at seven temperature-monitoring stations along the Colorado River. Bold italics indicate missing values that were estimated. Missing values for stratum 1 were estimated by using the relationship between thermal growth units there and at the stratum 3 or stratum 5 sites; missing values for strata 3 and 6 were estimated from stratum 5 values; missing values for the Rulison (R) site were estimated from the Cameo (C) site values. No thermograph was located in stratum 7 during the 1992-1996 period; all yearly totals are estimates based on the relationship between thermal growth units there and at the Cameo site (a ratio of 1.165:1) developed during 1986-1991 (not shown); Rkm = river kilometers upstream of the confluence with the Green River.

\begin{tabular}{|c|c|c|c|c|c|c|c|}
\hline \multicolumn{2}{|c|}{ Location } & \multirow{2}{*}{\multicolumn{5}{|c|}{ Year }} & \multirow[b]{3}{*}{ Mean $(\mathrm{SE})$} \\
\hline \multirow{2}{*}{$\begin{array}{c}\text { Stratum } \\
\text { or site }\end{array}$} & \multirow[b]{2}{*}{$\mathrm{Rkm}$} & & & & & & \\
\hline & & 1992 & 1993 & 1994 & 1995 & 1996 & \\
\hline 1 & 87.4 & 100.9 & 68.3 & 97.6 & 53.1 & 85.2 & $81.0(9.0)$ \\
\hline 3 & 158.2 & 85.3 & 53.5 & 96.7 & 47.2 & 77.2 & $72.0(7.5)$ \\
\hline 5 & 214.6 & 73.6 & 46.2 & 87.4 & 39.2 & 65.9 & $62.5(7.5)$ \\
\hline 6 & 264.7 & 63.9 & 41.3 & 75.9 & 34.6 & 59.4 & $55.0(8.8)$ \\
\hline 7 & 292.8 & 60.4 & 34.0 & 68.8 & 29.7 & 49.3 & $48.4(9.4)$ \\
\hline $\mathrm{C}$ & 321.4 & 51.9 & 29.2 & 59.1 & 25.5 & 42.3 & $41.6(6.4)$ \\
\hline $\mathrm{R}$ & 369.9 & 40.4 & 22.8 & 46.6 & 19.1 & 33.8 & $32.5(5.2)$ \\
\hline
\end{tabular}


rkm; and between Cameo and Rulison sites by $0.19 / \mathrm{rkm}$.

\section{Discussion}

This study coincided with the recruitment of two or three consecutive strong year-classes to the adult Colorado squawfish population. This allowed us to monitor the movements of many individual fish and observe changes in adult distribution resulting from these year-classes. Dispersal was generally in an upstream direction, but recruitment also increased adult abundance riverwide. Mean lengths increased in the lower reach as young fish grew, and the influx of young adults moving to the upper reach from the lower reach reduced average sizes of fish in the upper reach.

Distance moved between captures was related to fish size and reach of initial capture. Most fish initially captured in the upper reach moved little from initial capture sites and were predominately larger adults. However, most fish initially captured in the lower reach were smaller individuals and were often recaptured farther than $10 \mathrm{~km}$ from initial capture sites. In both reaches the majority of movements were directed upstream. These movement patterns suggest that young fish move more than older fish, and less movement occurs after arrival in the upper reach. Flannelmouth suckers in the White River behaved in a similar way with young individuals having moved more than older ones (Chart and Bergersen 1992).

Movement to upstream strata by adults suggests that upper reach habitats are preferred or have a better mix of requisites for growth and survival. Particularly revealing was the lack of fish movements from the upper reach to the lower reach. Riverwide catch rate patterns of larger prey species combined with reach differences in Colorado squawfish body condition support the hypothesis that upstream displacements are a response to food resource gradients.

Relatively small changes in location by larger fish in the upper reach was consistent with the hypothesis that adult Colorado squawfish select and maintain fidelity to a home feeding range, as suggested by Tyus (1990), McAda and Kaeding (1991), and Ryden and Ahlm (1996). Adults of this species appear not to be highly territorial (as defined by Hixon 1980) given that they concentrate in limited backwater habitats during spring runoff (April-June), they congregate prior to and during spawning in summer (Tyus 1990), and individuals are occasionally located (via radiotelemetry) be- side one another (USFWS, unpublished data) during base flows of fall and winter.

High relative condition of Colorado squawfish 200-399 $\mathrm{mm}$ in the lower reach suggests that food for young Colorado squawfish was not limited (at least during spring), and may relate to the high numbers of small-bodied, nonnative minnows in backwaters there. However, relative condition declined in the lower reach as Colorado squawfish grew, suggesting that a diet consisting of small minnows may be insufficient for larger individuals. If so, the lack of appropriate-sized prey may be particularly acute in the lower reach where warmer temperatures increase metabolic demands. Although little is known of food habits of larger adult Colorado squawfish (and we were unsuccessful in collecting such data), anecdotal evidence indicates consumption of larger prey than was found for size-classes examined in this study. A 687-mm Colorado squawfish captured in the San Juan River regurgitated a flannelmouth sucker 235 $\mathrm{mm}$ long-34\% of its own length (D. Propst, New Mexico Department of Game and Fish, personal communication). One $860-\mathrm{mm}$ individual that we captured in the lower Gunnison River regurgitated a 310-mm white sucker $\times$ bluehead sucker hybrid (36\% of its length). An X-rayed, 599-mm adult from the White River contained a $280-\mathrm{mm}(47 \%$ of its length) unidentified sucker (J. Hawkins, LFL, personal communication). Scott and Crossman (1973) reported the optimum food size of northern pike was one-third to one-half the pike's length and that growth and survival of large muskellunge are often impaired if food of an adequate size is not available, despite vast numbers of smaller fishes. Gillen et al. (1981) similarly reported an optimum prey size for tiger muskellunge $E$. lucius $\times$ E. masquinongy as $40 \%$ of total predator length when prey were soft-rayed and fusiform shaped. Also, of three simulated mechanisms, lack of large prey had the strongest effect on stunting of northern pike (Diana 1987).

The most downstream thermograph site provided the most days with temperatures at or near $25^{\circ} \mathrm{C}$, the preferred temperature of yearling (Black and Bulkley 1985a) and adult Colorado squawfish (Bulkley et al. 1981), and the greatest number of annual thermal units for growth. In addition, mainchannel temperatures there never became too warm for these fish: daily averages never exceeded $26^{\circ} \mathrm{C}$ during 4 years of monitoring. Therefore, growth potential should be highest in the lower reach. However, warm water temperatures there may be disadvantageous for adults: higher meta- 
bolic demands require more food, but appropriate food for adults is scarce.

Evidently the motivation for upstream dispersal is strong given that these movements are against the current and away from a more preferred thermal regime. Stuntz and Magnuson (1976) reported that preferred temperatures of bluegills Lepomis macrochirus decreased in laboratory studies as food ration decreased, and they suggested that bluegills use temperature selection as a method of decreasing weight loss during periods when daily rations are low. We suggest here that this same phenomenon, acting in concert with searches for greater food availability, motivate upstream dispersal in Colorado squawfish and result in the longitudinal structuring of size distributions observed in the Colorado River.

Factors other than changing food requirements may induce long-range displacements by adult Colorado squawfish; these include predator avoidance, reproduction, and physical habitat preferences. Of these, predator avoidance is probably least important given the rarity of predators capable of preying on adult Colorado squawfish. Because seasonal movements related to spawning were excluded from our analyses, displacements from one spring period to the next were probably not the direct result of reproductive behavior; that is, Colorado squawfish generally return to nonspawning home ranges by late summer or fall (Tyus 1990; McAda and Kaeding 1991). Searches for areas containing preferred meso- or microhabitats may contribute to observed movements and distribution, particularly within strata. However, because habitat and food are so tightly interrelated, it is difficult to separate selection for food from selection for habitat types that allow efficient foraging (Magnuson et al. 1979). It seems reasonable to assume that in an environment with minimal intraspecific competition and predation risk, positioning of adults, both within and among strata, would be primarily driven by growth maximization (see Hughes 1998), and growth is largely dependent on the interaction of temperature and food availability (Weatherley 1972). Achieving maximum growth potential enhances the ability of the individual to survive and reproduce successfully. In many fish species, large females produce more and larger eggs, thereby enhancing larval survival (Monteleone and Houde 1990; Brandt and Kirsch 1993).

Adults probably select reaches containing the best combination of resources, and the upper reach, particularly strata 6 and 7 (the Grand Valley) where adults were most concentrated, may represent the best balance between suitable temperatures and food availability. At some distance upstream, annual thermal units should decline to the point where plentiful forage can no longer provide adequate compensation, resulting in reduced growth. This probably occurs within the reach immediately upstream of the Grand Valley where annual thermal units are low. At Rulison, mean daily temperatures never reached $20^{\circ} \mathrm{C}$ during 3 of the 5 years studied. Black and Bulkley (1985b) found that growth of yearling Colorado squawfish held at $20^{\circ} \mathrm{C}$ and fed unlimited food was only $54 \%$ that of growth at the optimum temperature of $25^{\circ} \mathrm{C}$. This reach, blocked by diversion structures since the turn of the century, may represent the fringe of the former range of this species in the Colorado River.

Seasonal timing of and stimulus for movement could not be discerned in this study by comparing consecutive capture events. However, the available evidence allows us to offer four hypotheses. First, movements may be motivated by hunger with upstream exploration for food being more rewarding than downstream exploration. Second, an innate physiological mechanism may prompt upstream movement; however, the lack of dispersal movements in many fish and the downstream movement of some are counter to a species-wide directional disposition. Third, movements may be motivated by the urge to spawn, and better feeding areas are discovered in the process. Movement primarily by sexually mature individuals supports the latter hypothesis, but sizable numbers of adult fish are found in upper White and Yampa river reaches far upstream of their spawning areas (Tyus 1990), suggesting that upstream feeding areas were not located while en route to a spawning site.

A fourth hypothesis, combining the hunger and spawning hypotheses above, may be the most plausible given all lines of circumstantial evidence. Gradients in food resources may be discovered by young adults during their initial spawning migrations, and these learned gradients are then pursued after the spawning period is completed, resulting in further upstream explorations by young adults. If this latter hypothesis has merit, we might predict that such displacements take place during and immediately following the spawning period.

The extent to which distribution and dispersal patterns observed in this study reflect historic conditions is unknown. Intraspecific competition formerly might have played a role in structuring riverwide size distributions; now such competition in 
the upper reach is probably low given the relative rarity of these endangered fish. Also, nursery areas might not have been exclusively located in the lower reach as is largely the case today: data from the mid-1970s indicate that small size-classes of Colorado squawfish were much more abundant in the upper reach (see Osmundson and Burnham 1998). Predation from introduced largemouth bass Micropterus salmoides and green sunfish Lepomis cyanellus, now commonly found in upper-reach backwaters, may partly explain the current lack of young Colorado squawfish there. Also, prey of large Colorado squawfish (native suckers and chubs) may have once been more abundant in the lower reach than is the case today. The overall pattern observed in this study (i.e., large fish upstream; younger fish downstream), makes sense as a life history strategy and may partially reflect an adaptation to modified riverine conditions. The lower reach provides warmer water and ample food for early life phases when rapid growth is most important for survival; the upper reach provides moderated temperatures and more appropriately sized prey for adults when maintaining body condition may be important in gamete production and in fueling spawning migrations.

Long-distance dispersal is a manifestation of the individual's solution to spatial and temporal problems (Baker 1982), and exploratory movements across considerable distances are probably searches for suitable habitats (McKeown 1984). The distribution and dispersal patterns of Colorado squawfish in the Colorado River indicate that dispersal movements of this species occur at the landscape scale, and large sections of river are required to meet the changing needs of different life stages.

\section{Acknowledgments}

We thank Bruce Bonar, Tom Fresquez, Mike Montagne, and Dale Ryden for assisting with data collection and Frank Pfeifer for administrative support. We also thank Mike Farmer of the Larval Fish Laboratory, who performed diet analysis, and Charles McAda, who provided data on backwater area and small fish abundance. Kevin Bestgen, John Hawkins, Patrick Martinez, Tom Nesler, David Propst, Harold Tyus, Richard Valdez, and an anonymous reviewer provided valuable comments on earlier versions of this manuscript. This research was funded by the U.S. Fish and Wildlife Service and the Recovery Implementation Program for Endangered Fish Species in the Upper Colorado River basin.

\section{References}

Anderson, R. O., and S. J. Gutreuter. 1983. Length, weight, and structural indices. Pages 283-300 in L. A. Nielsen and D. L. Johnson, editors. Fisheries techniques. American Fisheries Society, Bethesda, Maryland.

Baker, R. R. 1982. Migration, paths through time and space. Hodder and Stoughton, London.

Belknap, B., and B. Belknap. 1974. Canyonlands river guide. Westwater Books, Belknap Photographic Services, Boulder City, Nevada.

Beyerle, G. B., and J. E. Williams. 1968. Some observations of food selectivity by northern pike in aquaria. Transactions of the American Fisheries Society 97:28-31.

Black, T., and R. V. Bulkley. 1985a. Preferred temperature of yearling Colorado squawfish. Southwestern Naturalist 30:95-100.

Black, T., and R. V. Bulkley. 1985b. Growth rate of yearling Colorado squawfish at different water temperatures. Southwestern Naturalist 30:253-257.

Brandt, S. B., and J. Kirsch. 1993. Spatially explicit models of striped bass growth potential in Chesapeake Bay. Transactions of the American Fisheries Society 122:845-869.

Bulkley, R. V., C. R. Berry, R. Pimentel, and T. Black. 1981. Tolerance and preferences of Colorado River endangered fishes to selected habitat parameters. Pages 185-241 in Part 3, Colorado River Fishery Project, Final Report. U.S. Fish and Wildlife Service and Bureau of Reclamation, Contracted Studies, Salt Lake City, Utah.

Chart, T. E., and E. P. Bergersen. 1992. Impact of mainstream impoundment on the distribution and movements of the resident flannelmouth sucker (Catostomidae: Catostomus latipinnis) population in the White River, Colorado. Southwestern Naturalist 37: 9-15.

Diana, J. S. 1987. Simulation of mechanisms causing stunting in northern pike populations. Transactions of the American Fisheries Society 116:612-617.

Gengerke, T. W., D. G. Unkenholz, and J. G. Nickum. 1973. A modification of Seaburg's stomach sampler. Progressive Fish-Culturist 35:142.

Gillen, A. L., R. A. Stein, and R. F. Carline. 1981. Predation by pellet-reared tiger muskellunge on minnows and bluegills in experimental systems. Transactions of the American Fisheries Society 110:197209.

Hawkins, J. A. 1992. Age and growth of Colorado squawfish from the upper Colorado River basin, 1978-1990. Master's thesis. Colorado State University, Fort Collins, Colorado.

Haynes, C. M., T. A. Lytle, E. J. Wick, and R. T. Muth. 1984. Larval Colorado squawfish (Ptychocheilus lucius Girard) in the upper Colorado River basin, Colorado, 1979-1981. Southwestern Naturalist 29:2133.

Hixon, M. A. 1980. Food production and competitor density as the determinants of feeding territory size. American Naturalist 115:510-530. 
Hughes, N. F. 1998. A model of habitat selection by drift-feeding stream salmonids at different scales. Ecology 79:281-294.

Jernejcic, F. 1969. Use of emetics to collect stomach contents of walleye and largemouth bass. Transactions of the American Fisheries Society 98:698702.

Juanes, F. 1994. What determines prey size-selectivity in piscivorous fishes. Pages 79-100 in D. J. Stouder, K. L. Fresh, and R. J. Feller, editors. Theory and application in fish feeding ecology. University of South Carolina Press, Columbia.

Kaeding, L. R., and D. B. Osmundson. 1988. Interaction of slow growth and increased early-life mortality: an hypothesis on the decline of Colorado squawfish in the upstream regions of its historic range. Environmental Biology of Fishes 22:287-298.

Le Cren, E. D. 1951. The length-weight relationship and seasonal cycle in gonad weight and condition in the perch (Perca fluviatilis). Journal of Animal Ecology 20:201-219.

Magnuson, J. J., L. B. Crowder, and P. A. Medvick. 1979. Temperature as an ecological resource. American Zoologist 19:331-343.

Mauck, M. L., and D. W. Coble. 1971. Vulnerability of some fishes to northern pike (Esox lucius) predation. Journal of the Fisheries Research Board of Canada 28:957-969.

McAda, C. W. 1983. Colorado squawfish, Ptychocheilus lucius (Cyprinidae), with a channel catfish, Ictalurus punctatus (Ictaluridae), lodged in its throat. Southwestern Naturalist 28:119-120.

McAda, C. W., and five coauthors. 1994. Interagency standardized monitoring program: summary of results, 1986-1992. U.S. Fish and Wildlife Service, Recovery Implementation Program, Final Report, Denver.

McAda, C. W., and L. R. Kaeding. 1991. Movements of adult Colorado squawfish during the spawning season in the upper Colorado River. Transactions of the American Fisheries Society 120:339-345.

McKeown, B. A. 1984. Fish migration. Timber Press, Beaverton, Oregon.

Monteleone, D. M., and E. D. Houde. 1990. Influence of maternal size on survival and growth of striped bass Morone saxatilis Walbaum eggs and larvae. Journal of Experimental Marine Biology and Ecology 140:1-11.

Nelson, J. S., and five coauthors. 1998. Recommended changes in common fish names; pikeminnow to replace squawfish (Ptychocheilus spp.). Fisheries 23(9):37.

Nesler, T. P., R. T. Muth, and A. Wasowicz. 1988. Evidence for baseline flow spikes as spawning cues for Colorado squawfish in the Yampa River, Colorado. Pages 68-79 in R. D. Hoyt, editor. 11th annual larval fish conference. American Fisheries Society, Symposium 5, Bethesda, Maryland.

Osmundson, D. B., and K. P. Burnham. 1998. Status and trends of the endangered Colorado squawfish in the upper Colorado River. Transactions of the American Fisheries Society 127:957-970.
Osmundson, D. B., and L. R. Kaeding. 1989. Studies of Colorado squawfish and razorback sucker use of the '15-mile reach' of the upper Colorado River as part of conservation measures for the Green Mountain and Ruedi reservoir water sales. U.S. Fish and Wildlife Service, Final Report, Grand Junction, Colorado.

Ryden, D. W., and L. A. Ahlm. 1996. Observations on the distribution and movements of Colorado squawfish, Ptychocheilus lucius, in the San Juan River, New Mexico, Colorado, and Utah. Southwestern Naturalist 41:161-168.

Scott, W. B., and E. J. Crossman. 1973. Freshwater fishes of Canada. Fisheries Research Board of Canada Bulletin 184.

Seaburg, K. G. 1957. A stomach sampler for live fish. Progressive Fish-Culturist 19:137-139.

Stuntz, W. E., and J. J. Magnuson. 1976. Daily ration, temperature selection, and activity of bluegill. Pages 180-184 in G. W. Esch and R. W. McFarlane, editors. Thermal ecology II. National Technical Information Service, CONF-750425, Springfield, Virginia.

Swanson, G. A., G. L. Krapu, J. C. Bartonek, J. R. Serie, and D. H. Johnson. 1974. Advantages in mathematically weighting waterfowl food habits data. Journal of Wildlife Management 38:302-307.

Tyus, H. M. 1985. Homing behavior noted for Colorado squawfish. Copeia 1985:213-215.

Tyus, H. M. 1986. Life strategies in the evolution of the Colorado squawfish (Ptychocheilus lucius). Great Basin Naturalist 46:656-661.

Tyus, H. M. 1990. Potamodromy and reproduction of Colorado squawfish in the Green River basin, Colorado and Utah. Transactions of the American Fisheries Society 119:1035-1047.

Tyus, H. M., and G. B. Haines. 1991. Distribution, habitat use, and growth of age-0 Colorado squawfish in the Green River basin, Colorado and Utah. Transactions of the American Fisheries Society 120:7989.

Tyus, H. M., and C. W. McAda. 1984. Migration, movements, and habitat preferences of Colorado squawfish, Ptychocheilus lucius, in the Green, White, and Yampa rivers, Colorado and Utah. Southwestern Naturalist 29:289-299.

Valdez, R. A., P. G. Mangan, R. P. Smith, and B. C. Nilson. 1982. Upper Colorado River investigation (Rifle, Colorado to Lake Powell, Utah). Pages 101279 in Part 2, Colorado River Fishery Project, Final Report. U.S. Fish and Wildlife Service and Bureau of Reclamation, Field Investigations, Salt Lake City, Utah.

Wahl, D. H., and R. A. Stein. 1988. Selective predation by three esocids: the role of prey behavior and morphology. Transactions of the American Fisheries Society 117:142-151.

Weatherley, A. H. 1972. Growth and ecology of fish populations. Academic Press, New York.

Received August 22, 1997 Accepted April 27, 1998 